\title{
Исследование физико-химического состава и технологических свойств овечьего и козьего молока в летний период лактации
}

\author{
Оспанов Асан Бекешович \\ ТОО «Казахский научно-исследовательский институт \\ перерабатывающей и пищевой промышленности» \\ Адрес: 050060, г. Алматы, пр. Гагарина, д. $238 \ll Г »$ \\ E-mail:a.ospanov@rpf.kz
}

Құлжанова Ботагөз Оңдасынқызы

ТОО «Казахский научно-исследовательский институт перерабатывающей и пищевой промышленности» Адрес: 050060, г. Алматы, пр. Гагарина, д. $238 « Г »$

E-mail:botagoz-89@mail.ru

\begin{abstract}
Щетинина Елена Михайловна ФГБОУ ВО Московский государственный университет пищевых производств Адрес: 125080, г. Москва, Волоколамское шоссе, Ә. 11

E-mail: schetinina2014@bk.ru
\end{abstract}

Велямов Шухрат Масимжанович

ТОО «Казахский научно-исследовательский институт перерабатывающей и пищевой промышленности» Адрес: 050060, г. Алматы, пр. Гагарина, 238 «» E-mail:sh.velyamov@rpf.kz

Макеева Раушан Кыдырхановна

ТОО «Казахский научно-исследовательский институт перерабатывающей и пищевой промышленности» Адрес: 050060, г. Алматы, пр. Гагарина, д. 238 «Г» E-mail:r.makeyeva@rpf.kz

Бектурсунова Мая Джумадиловна ТОО «Казахский научно-исследовательский институт перерабатывающей и пищевой промышленности» Адрес: 050060, г. Алматы, пр. Гагарина, д. 238 «Г» E-mail: m.bektursunova@rpf.kz

\begin{abstract}
В статье представлены результаты исследования физико-химического состава и технологических свойств овечьего и козьего молока в летний период лактации (с июня по август 2021 года) по 4 породам овец (Казахский тонкорунный, Южноказахский меринос, Едильбай и Иль Де Франц) и 4 породам коз (Зааненская, Нубийская, Альпийская и Бурская) из различных регионов Казахстана. Изучен содержание жира и белка в молоке. Разница в содержании белка в летний период не превышает от 0,1 до 0,5 \%, высокое содержание жира отмечалось в августе месяце (5,4\% для овец и 3,6\% для ко3), а самое низкое в июле месяце (4,9\% для овец и 3,2 \% для коз), это связано с климатическими условиями, в июле стоит жаркая погода и животные пьют больше воды и испытывают стрессы погодных аномалий а также летом основа рациона - пастбищный
\end{abstract}


травостой, животные потребляют зеленый корм, содержащий много влаги. В августе значения показателей повышаются, так как многие кормовые культуры к этому времени созревают и питательная ценность, соответственно, возрастает.

Ключевые слова: молоко, овечье молоко, козье молоко, летний период лактации

\section{Введение}

Казахстан является импортозависимой страной в отношении молочной продукции, особенно по творогам и йогуртам, по сырам и по сухому молоку. Ассортимент отечественного производства небольшой, недостаточно производятся молокопродукты функционального назначения по возрастным категориям. В Казахстане промышленно освоено только коровье молоко, в регионах начали перерабатывать козье молоко, а овечье молоко вовсе не является источником молочных продуктов, хотя овец насчитывает более 18 млн. голов. По статистическим данным за 2020 год поголовье коз достигло более $2,2 \mathrm{Mлн.}$

В мире идет неуклонный рост потребления продуктов из овечьего и козьего молока ${ }^{1}$, как всех видов молочных продуктов, так и продуктов детского и лечебного питания, что обуславливается высокой питательной ценностью, гипоаллергенными свойствами овечьего и козьего молока (Оспанов, Алимарданова, \& Токсанбаева, 2017; Оспанов, Алимарданова, \& Токсанбаева, 2018; Щетинина, Гаврилова, Чернопольская, \& Coловьева, 2021).

Продукты из козьего молока более подходят для здоровья человека, с меньшей частотой аллергических реакций (Zeman \& Ney, 1982; Saini \& Gill, 1991; Haenlein, 1993) и полезны для лечения других заболеваний, таких как желудочно-кишечные, сердечно-сосудистые и связанные со стрессом заболевания (Babayan, 1981). При использовании молока в качестве сырья для производства йогурта наиболее важными показателями являются содержание белков, липидов, лактозы и минералов (Walstra, Geurts, Noomen, Jellema, \& van Boekel, 1999). Некоторые исследователи указывают, что состав молока овец и коз различается не только содержанием вышеотмеченных ключевых веществ (Jandal, 1996; Pandya \& Ghodke, 2007; Park, Juárez, Ramos, \& Haenlein, 2007; Park, 2007) но и их типом, таких как казеины или мицеллярные структуры (Grandison, 1986).
Исследования зарубежных ученых и наши поиски подтверждают высокотехнологичность и эффективность использования овечьего и козьего молока для производства кисломолочных продуктов и сыров (Jandal, 1996; Myrkalykov, Tulekbaeva, Shingisov, Ospanov, \& Simov, 2016; Dimitrov, D., Simov, Ospanov, \& Dimitrov, Z., 2015; Мыркалыков, Оспанов, Симов, \& Шингисов, 2016; Park, 2007).

Мицеллы казеина козьего молока содержат больше кальция и неорганического фосфора. Липиды в овечьем и козьем молоке представлены жировыми глобулами меньшего размера, что способствует лучшей усвояемости организмом человека (Ospanov, Zhakupova, \&Toxanbayeva, 2018; Muldasheva, Toxanbayeva, Ospanov, \& Zhakupova, 2019; Kasapidou et al., 2021), тем самым усиливается функциональность молочной продукции.

Состав и свойства овечьего молока в первую очередь зависят от ряда физиологических факторов - породы, изменчивости между отдельными животными, стадии лактации, сезонных колебаний, способа выращивания и кормления животных, возраста, различных заболеваний и др. (Tamime, Wszolek, Božanić, \& Ozer, 2011; Claeys et al., 2014; Sajko-Matutinović, et al., 2012; Milewski, Ząbek, Antoszkiewicz, Tański, \& Sobczak, 2018).

Таким образом, для Казахстана овечье и козье молоко представляет большой потенциал для расширения ассортимента и повышения экспорта молочной продукции, ведь только рынки соседних стран, как России и Китая, имеют огромную емкость кисломолочных продуктов (Ospanov \& Toxanbayeva, 2020).

В связи с вышеизложенными, нами поставлена цель - исследовать физико-химические и технологических свойства молока некоторых казахстанских пород овец и коз из различных регионов в летний период лактации, что позволит описать общую картину районированного сырья и оценить технологическую пригодность его переработки.

\footnotetext{
Программа всемирной сельскохозяйственной переписи 2020 года. Продовольственная и сельскохозяйственная организация Объединенных Наций. (2016). Рим: Продовольственная и сельскохозяйственная организация объединенных наций. URL: http://www.fao.org/3/a-i4913r.pdf (дата обращения: 10.04.2021).
} 


\section{Материалы и методы}

\section{Объекты исследования}

Для экспериментальных исследований подобрано молоко-сырье из различных фермерских хозяйств и частных подворий. На юге Казахстана наибольшее распространение нашли породы овец как, южно-казахстанский меринос, Еділбай, Иль де Франц, а также коз породы - Зааненская, Нубийская, Альпийская и Бурская.

\section{Методы исследования}

Экспериментальные исследования по определению физико-химического состава и технологических свойств овечьего и козьего молока проведены в соответствии с национальными стандартами.

Органолептическую оценку молока проводили согласно стандартам СТ РК 1732-2007² и ГОСТу 32940-201433 комиссионно профильным методом по 5-балльной шкале $(0,3$ и 5 баллов) в соответствии с регламентом проведения дегустаций. Под органолептическими свойствами молока понимают свойства, воспринимаемые органами чувств: внешний вид, цвет, вкус и запах, консистенция, которые зависят от содержания всех составных компонентов молока и его физико-химических показателей

Физико-химические показатели молока (содержания жира, белка и точки замерзания) определяли на приборе «Лактан - 600 Ультрамакс» откалиброванного под овечье и козье молоко.

Вязкость определяли на вискозиметре Brookfield DV2T.

Влажность определяли согласно ГОСТ $3626-73^{4}$ на анализаторе влажности «Элекс-7».

Содержание сухих веществ выводили расчетным путем.

Термоустойчивость - пригодность молока для высокотемпературной обработки (стерилизации, ультрапастеризации) устанавливали по алкогольной пробе, основанной на воздействии разных концентраций этилового спирта на молоко. Термоустойчивость молока определяли согласно ГОСТ 25228-82

Титруемую кислотность определяли согласно ГОСТ 3624-926, активную кислотность (Ph) согласно ГОСТ 32892-20147.

\section{Процедура исследования}

В крестьянском хозяйстве «Акша» Жамбылской области был проведен хозяйственный опыт на четырех группах лактирующих овец и на четырех группах лактирующих коз.

В первую группу лактирующих овец входили овцы Казахской тонкорунной породы, во вторую - Южноказахский меринос, в третью - Еділбай, в четвертую - ИДФ, а также в первую группу лактирующих коз входили козы породы Бурская, во вторую - Зааненская, в третью - Нубийская, в четвертую - Альпийская. На начало опыта все животные были на 30...40-ом дне лактации, исследование молочной продуктивности проводили на всем периоде лактации.

Для экспериментов молоко отбирали с июня месяца по август 2021 года из 10 овец и коз каждой породы. Забор молока проводили в утреннюю дойку. Показатели молока исследовали с использованием стандартных методов в лаборатории «Биотехнология, качество и безопасность пищевых продуктов» Казахского научно-исследовательского института перерабатывающей и пищевой промышленности.

В пастбищный период принято содержать овец на выпасах и дополнительно подкармливать концентратами. При недостатке травы на пастбище, подкармливали сеном и другими доступными кормами. Доступ к воде и соли был без ограничения. Рацион питания у овец и коз несколько отличается, а по видам животных рацион практически был одинаковым. По предварительным исследованиям установлено, что у овец и коз, содержащихся

\footnotetext{
2 СТ РК 1732-2007. (2015). Молоко и молочные продукты. Органолептический метод определения показателей качества. Астана: Мемстандарт.

3 ГОСТ 32940-2014. (2018). Молоко козье сырое. Технические условия. М.: Стандартинформ.

4 ГОСТ 3626-73 (2009). Молоко и молочные продукты. Методы определения влаги и сухого вещества. М.: Стандартинформ. ГОСТ 25228-82. Молоко и сливки. Метод определения термоустойчивости по алкогольной пробе.

м.: Стандартинформ.

6 ГОСТ 3624-92. (2009). Молоко и молочные продукты. Титриметрические методы определения кислотности. М.: Стандартинформ.

7 ГОСТ 32892-2014. Молоко и молочная продукция. Метод измерения активной кислотности. М.: Стандартинформ.
} 
на пастбище, содержание жира и белка в молоке выше, чем на полном рационе в стойлах.

Статистический анализ данных проводили с использованием статистической программы SPSS версии 13 (SPSS Inc., Чикаго, Иллинойс, США). Дисперсионный анализ (ANOVA) и критерий множественных диапазонов Дункана использовали для определения значительных различий между результатами. 95\% доверительной вероятности результатов выборки достигали при повторности экспериментов $n=5$.

\section{Результаты исследования}

Результаты органолептической оценки молока приведены в Таблице 1.

Органолептические исследования проб молока, взятых с КX «Акша», дали хорошие результаты, соответствующие гостам.

Продуктивность овец и коз во многом зависит от породы животного и условий их содержания (Таблица 2).

Из данных таблицы видно, что суточный удой овцематок составляет 0,55 кг у овец породы ИДФ, 1,78 кг у Едилбайской породы, у Южноказахского мериноса - 1,13 кг и у Казахской тонкорунной породы - 0,93 кг. Наибольшая молочность за всю лактацию отмечена у маток породы ИДФ (169 кг), минимальную молочность имеют матки породы Казахская тонкорунная (112 кг) и Еділбай $(98$ кг).
Таблица 1

Органолептические показатели овечьего и козьего молока

\begin{tabular}{ll}
\hline \multicolumn{1}{c}{ Показатель } & \multicolumn{1}{c}{ Фактический результат } \\
\hline & \multicolumn{1}{c}{ Овечье молоко } \\
\hline Цвет & Белый, со слегка желтоватым оттенком \\
Запах & Чистый, без постороннего запаха \\
Внешний вид и & Густая однородная жидкость без хлопьев \\
консистенция & \\
Вкус & Приятный, сладковатый \\
\hline & \multicolumn{1}{c}{ Козье молоко } \\
\hline Цвет & Белый \\
Запах & Чистый, без посторонних запахов \\
Внешний вид и & Однородная жидкость, без \\
консистенция & осадка и хлопьев \\
Вкус & Слабый специфический прив- \\
& кус свойственный козьему молоку \\
\hline
\end{tabular}

Анализ молочной продуктивности коз разных пород показал, что козы Зааненской породы превосходили сверстниц Альпийской, Нубийской и Бурской пород по удою за 300 дней лактации и имели по сравнению с ними более высокие среднесуточные удои. При этом достоверное преимущество по удою коз Зааненской породы было лишь по сравнению с животными Альпийской породы.

В молочной промышленности при производстве кисломолочных продуктов используется высокотемпературная обработка. Поэтому оценка молока

Таблица 2

Продуктивность овец и коз в зависимости от породы

\begin{tabular}{lccc}
\hline \multicolumn{1}{c}{ Название породы } & Лактация, дней & Удой за сутки, кг & Удой за период лактации, кг \\
\hline \multicolumn{1}{c}{$\mathbf{1}$} & $\mathbf{2}$ & Порода овец & $\mathbf{4}$ \\
\hline Казахская тонкорунная & 120 & $\mathbf{3}$ & $112,13 \pm 2,5$ \\
Южноказах- & 124 & $1,13 \pm 0,12$ & $140 \pm 3,7$ \\
ский меринос & & & $98 \pm 1,6$ \\
Еділбай & 95 & $1,78 \pm 0,23$ & $169 \pm 3,4$ \\
Иль де Франс (ИДФ) & 178 & $0,55 \pm 0,01$ & \\
\hline & & Порода коз & $630,14 \pm 30,86$ \\
\hline Зааненская & 300 & $3,08 \pm 0,20$ & $608,70 \pm 83,64$ \\
Нубийская & 300 & $2,80 \pm 0,10$ & $534,17 \pm 43,64$ \\
Альпийская & 300 & $2,63 \pm 0,4$ & $424,12 \pm 43,64$ \\
Бурская & 300 & $2,33 \pm 0,4$ & \\
\hline
\end{tabular}


овец и коз по термоустойчивости и свертываемости имеет важное практическое значение.

Свежее молоко выдерживает высокотемпературную обработку без явных признаков коагуляции казеина. Низкую стойкость к нагреванию имеет молоко в начале лактации. К концу лактации термоустойчивость опять ухудшается. Таким образом, термоустойчивость белковых компонентов молока определяют в совокупности множество факторов это белковый состав, его кислотность и солевой баланс, которое к тому же зависит от стадии лактации, индивидуальных особенностей животного, времени года, составляющих рациона и т.д., под влиянием которых нарушаются во первых органолептические свойства молока, а потом уже и физико-химические и технологические свойства.

Проведённые нами исследования по оценке термоустойчивости по алкогольной пробе козьего и овечьего молока указали нам на выдерживание 75-80\% раствора этилового спирта, что подтверждает их термоустойчивость.

Содержание белка в молоке является одним из основных показателей, учитываемых при оценке биологической ценности молока.

Молочный жир - энергетический компонент молока и особенно подвержен изменениям под воздей- ствием различных факторов и может повышаться или снижаться в зависимости от типа кормления, периода лактации и т.д.

Средние показатели количественного содержания физико-химического состава овечьего и козьего молока представлены в Таблице 3.

Анализ проведенных исследований физико-химических свойств овечьего и козьего молока (Таблице 3) показал, что содержание сухих веществ (CB) в молоке изменяется в летний период лактации, но незначительно. Следует отметить, что наибольшее содержание СВ как в овечьем, так и в козьем молоке отмечается в августе. Также, незначительно меняется содержание белка и жира в молоке овец и коз, в рассмотренные месяцы лактации и не превышает 0,1-0,5\%. Самое высокое содержание жира отмечалось в августе месяце $(5,4 \%$ у овец и 3,6\% у коз), а низкое в середине лета - в июле месяце (4,9\% у овец и 3,2\% у коз).

Значения перечисленных показателей у всех исследуемых пород овец и коз снижаются в июле месяце. Считаем, что это связано с климатическими условиями. В июле текущего года в южных регионах Казахстана стояла сильная жаркая погода (до $+38^{\circ} \mathrm{C}$ ) и животные испытывали стрессы погодных аномалий. В августе значения показателей повышаются, так как многие кормовые культуры к это-

Таблица 3

Физико-химические показатели овечьего и козьего молока

\begin{tabular}{|c|c|c|c|c|c|c|}
\hline \multirow{3}{*}{ Показатели, \% } & \multicolumn{6}{|c|}{ Летний период } \\
\hline & \multicolumn{3}{|c|}{ Овечье молоко } & \multicolumn{3}{|c|}{ Козье молоко } \\
\hline & июнь & июль & август & июнь & июль & август \\
\hline 1 & 2 & 3 & 4 & 5 & 6 & 7 \\
\hline Массовая доля влаги & $85,5 \pm 0,80$ & $86,1 \pm 0,30$ & $85,14 \pm 0,27$ & $89,24 \pm 0,30$ & $89,58 \pm 0,27$ & $89,04 \pm 0,2$ \\
\hline Массовая доля & $14,5 \pm 0,40$ & $13,9 \pm 0,25$ & $14,86 \pm 0,18$ & $10,76 \pm 0,25$ & $10,42 \pm 0,75$ & $10,96 \pm 0,86$ \\
\hline \multicolumn{7}{|l|}{ сухих веществ } \\
\hline Жир & $5,2 \pm 0,2$ & $4,9 \pm 0,5$ & $5,4 \pm 0,3$ & $3,5 \pm 0,05$ & $3,2 \pm 0,04$ & $3,6 \pm 0,05$ \\
\hline Белок & $4,1 \pm 0,5$ & $3,9 \pm 0,1$ & $4,36 \pm 0,3$ & $3,11 \pm 0,01$ & $3,10 \pm 0,01$ & $3,20 \pm 0,02$ \\
\hline Активная & $6,61 \pm 0,01$ & $6,61 \pm 0,03$ & $6,61 \pm 0,01$ & $6,54 \pm 0,03$ & $6,56 \pm 0,01$ & $6,57 \pm 0,02$ \\
\hline \multicolumn{7}{|l|}{ кислотность, pH } \\
\hline Титруемая & $22 \pm 0,516$ & $22 \pm 0,513$ & $22 \pm 0,509$ & $16,37 \pm 0,403$ & $16,07 \pm 0,410$ & $16,02 \pm 0,420$ \\
\hline \multicolumn{7}{|l|}{ кислотность, ${ }^{\circ} \mathrm{T}$} \\
\hline 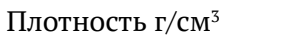 & 1,036 & 1,034 & 1,034 & 1,027 & 1,027 & 1,027 \\
\hline Точка замерзания, `T & $0,529 \pm 1,5$ & $0,529 \pm 1,5$ & $0,529 \pm 1,5$ & $0,500 \pm 1,2$ & $0,510 \pm 1,2$ & $0,510 \pm 1,2$ \\
\hline Вязкость, Па·С & $2,05 \cdot 10^{-3}$ & $2,1 \cdot 10^{-3}$ & $2,25 \cdot 10^{-3}$ & $1,5 \cdot 10^{-3}$ & $1,7 \cdot 10^{-3}$ & $1,8 \cdot 10^{-3}$ \\
\hline
\end{tabular}


му времени созрели, и их питательная ценность возросла.

Плотность молока у овец летом снижается от $1,036 г / \mathrm{cm}^{3}$ до $1,034 \Gamma / \mathrm{cm}^{3}$, а у козьего молока пока-

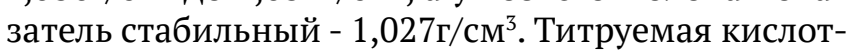
ность у молока овец остается на уровне $22^{\circ} \mathrm{T}$, а у молока коз снижается от $16,37^{\circ} \mathrm{T}$ до $16,02^{\circ} \mathrm{T}$.

Вязкость молока и у овец, и у коз к концу лета повышается от $2,05 \cdot 10^{-3}$ Па.С до $2,25 \cdot 10^{-3}$ Па $С$ и от $1,5 \cdot 10^{-3}$ Па $\cdot$ С до $1,8 \cdot 10^{-3} \Pi а \cdot C$, соответственно. Это объясняется повышением массовой доли жира и казеина, а также степени его дисперсности.

Изучено содержание жира и белка, а результаты представлены в Таблицах 4, 5, 6 и 7.

Таблица 4

Содержание жира в летний период лактации, (\%)

\begin{tabular}{lcccc}
\hline \multicolumn{1}{c}{ Породы овец } & \multicolumn{3}{c}{$\begin{array}{c}\text { Летний пери- } \\
\text { од лактации }\end{array}$} & \multirow{2}{*}{$\begin{array}{c}\text { В сред- } \\
\text { нем }\end{array}$} \\
\cline { 2 - 4 } & июнь & июль & август & \\
\hline $\begin{array}{l}\text { Казахская тон- } \\
\text { корунная }\end{array}$ & 5,2 & 4,9 & 5,4 & 5,16 \\
$\begin{array}{l}\text { Южноказах- } \\
\text { ский меринос }\end{array}$ & 4,1 & 4,0 & 4,15 & 4,08 \\
$\begin{array}{l}\text { Еділбай } \\
\text { ИДФ }\end{array}$ & 3,1 & 2,9 & 3,3 & 3,1 \\
\hline
\end{tabular}

Из Таблицы 4 видно, что за летний период лактации самый высокий показатель жирности (в среднем - 5,16\%) наблюдается у Казахской тонкорунной, а самый низкий у породы Еділбай $3,1 \%$.

Белки молока - это высокомолекулярные соединения, состоящие из аминокислот, связанных между собой характерной для белков пептидной связью и являющиеся самой ценной составной частью молока. Ценность белков состоит в наличии в них незаменимых аминокислот как - валин, лизин, лейцин, изолейцин, метионин, тирозин, триптофан, фенилаланин. По содержанию незаменимых аминокислот и соотношению между ними белки овечьего и козьего молока относят к биологически полноценным белкам.

Различие в содержании белка в молоке по месяцам лактации объясняется изменением рациона питания коз. Бедный энергией рацион приводит к уменьшению содержания белка, а богатый - к его увеличению. При дефиците протеина в пита- нии животных, соответственно снижается содержание белка в молоке.

Из Таблицы 5 видно, что содержание белка у разных пород варьируется, к концу летнего сезона у трех пород содержание белка незначительно увеличивается по сравнению с началом летнего сезона, снижение наблюдается в молоке породы Еділбай от 3,9\% до 3,84 \%.

Таблица 5

Содержание белка овечьего молока, (\%)

\begin{tabular}{lcccc}
\hline \multirow{2}{*}{ Породы овец } & \multicolumn{2}{c}{ Летний период лактации } & В сред- \\
\cline { 2 - 3 } & июнь & июль & август & нем \\
\hline $\begin{array}{l}\text { Южнока } \\
\text { захский меринос }\end{array}$ & 4,2 & 4,05 & 4,36 & 4,20 \\
$\begin{array}{l}\text { Казахская } \\
\text { тонкорунная }\end{array}$ & 4,1 & 3,96 & 4,34 & 4,13 \\
$\begin{array}{l}\text { Еділбай } \\
\text { ИДФ }\end{array}$ & 3,9 & 3,7 & 3,84 & 3,81 \\
\hline & 3,5 & 3,6 & 3,8 & 3,63 \\
\hline
\end{tabular}

Содержание жира в козьем молоке зависит от многих причин, например, от сезона года. В умеренном климате в конце осени в козьем молоке зарегистрированы самые низкие показатели жира и белка (Таблицы 6 и 7).

Таблица 6

Содержание белка козьего молока, (\%)

\begin{tabular}{lcccc}
\hline \multirow{2}{*}{ Породы коз } & \multicolumn{2}{c}{ Летний период лактации } & \multirow{2}{*}{ В сред- } \\
\cline { 2 - 4 } & июнь & июль & август & нем \\
\hline Бурская & 3,3 & 3,5 & 3,6 & 3,46 \\
Зааненская & 3,11 & 3,10 & 3,2 & 3,13 \\
Нубийская & 3,09 & 3,15 & 3,3 & 3,18 \\
Альпийская & 2,9 & 3 & 3,2 & 3,03 \\
\hline
\end{tabular}

Массовая доля белка в летний период повышается у всех пород, самый высокий показатель белка в молоке породы Бурская - 3,6 \%, затем Нубийская 3,3 \%, Зааненская и Альпийская - 3,2\%. В среднем за лето самый низкий показатель белка в молоке наблюдали у Альпийской породы - 3,03 \%.

В зависимости от месяца рассматриваемого сезона года, содержание жира в молоке может меняться на $2 \%$, а содержание белка на $1 \%$.

Анализ данных показал, что содержание жира в молоке растет по сравнению с началом сезона у всех пород коз, к концу сезона наибольшее коли- 
Таблица 7

Содержание жира козьего молока, (\%)

\begin{tabular}{ccccc}
\hline \multirow{2}{*}{ Породы коз } & \multicolumn{2}{c}{ Летний период лактации } & \multirow{2}{*}{ в сред- } \\
\cline { 2 - 3 } & июнь & июль & август & нем \\
\hline Бурская & 4,0 & 4,2 & 4,3 & 4,16 \\
Зааненская & 3,5 & 3,2 & 3,6 & 3,43 \\
Альпийская & 3,0 & 3,2 & 3,4 & 3,23 \\
Нубийская & 2,9 & 3,1 & 3,3 & 3,1 \\
\hline
\end{tabular}

чество массовой доли жира в молоке наблюдается у Бурской породы - 4,3\%, самый низкий показатель у породы Нубийская - 3,3\%.

\section{Выводы}

Резюмируя вышеотмеченные, можно сделать вывод о том, что химический состав и соотношение компонентов молока между собой практически не меняются или меняется незначительно.

- наибольшее содержание сухого вещества овечьего и козьего молока отмечено в августе месяце 9,46\% и 7,36\% соответственно, а наименьшее - в июле (9,0\% и 7,22 \%);

- $\quad$ разница в содержании белка в летний период не превышает от $0,1 \%$ до 0,5\%. Бедный энергией рацион приводит к уменьшению содержания белка, а богатый - к его увеличению. При дефиците протеина в питании животных, соответственно снижается содержание белка в молоке;

- высокое содержание жира отмечалось в августе месяце $(5,4 \%$ в молоке овец и $3,6 \%$ в молоке коз), а самое низкое в середине лета - в июле месяце (4,9\% в овечьем молоке и $3,2 \%$ в козьем молоке);

- проведённые нами исследования по оценке термоустойчивости по алкогольной пробе козьего и овечьего молока указали нам на выдерживание 75-80\% раствора этилового спирта, что подтверждает их термоустойчивость.

\section{Благодарности}

Статья была подготовлена в рамках исследований по научному проекту «Разработка технологии живого йогурта на основе молока мелкого рогатого скота с капсулированным плодово-ягодным концентратом» по грантовому финансированию Комитета науки Министерства образования и науки Республики Казахстан на 2020-2022 годы.

\section{Литература}

Мыркалыков, Б. С., Оспанов, А. Б., Симов, Ж. И., \& Шингисов, А. У. (2016). Разработка потребительских критериев для оценки качества маркировки овечьего молоко и продуктов его переработки. Исследования, результаты, 4, 120-131.

Оспанов, А. Б., Алимарданова, М. К., \& Токсанбаева, Б. О. (2017). Потенциал молочной отрасли Казахстана. В Техника и технология пищевых производств: Материалы XI международной научно-технической конференции (с. 13-15). Могилев: Могилевский государственный университет продовольствия.

Оспанов, А. Б., Алимарданова, М. К., \& Токсанбаева, Б. О. (2018). Состав овечьего и козьего молока в Казахстане. В Техника и технология пищевых производств: Материалы XII международной научно-технической конференции (т. 1, с. 373-374). Могилев: Могилевский государственный университет продовольствия.

Щетинина, Е. М., Гаврилова, Н. Б., Чернопольская, Н. Л. \& Соловьева, Н. И. (2021). Инновационная технология полутвёрдого сыра из козьего молока для специализированного питания. Хранение и переработка сельхозсырья, 1 , 93-104. https://doi.org/10.36107/spfp.2021.193

Babayan, V. K. (1981). Medium chain length fatty acid esters and their medical and nutritional application. Journal of the American Oil Chemists Society, 58(1), 49A-51A. https://doi.org/10.1007/ BF02666072

Claeys, W. L., Verraes, C., Cardoen, S., De Block, J., Huyghebaert, A., Raes, K., Dewettinck, L., \& Herman, L. (2014). Consumption of raw or heated milk from different species: An evaluation of the nutritional and potential health benefits. Food Control, 42, 188-201. https://doi.org/10.1016/j. foodcont.2014.01.045

Dimitrov, D., Simov, Zh., Ospanov, A., \& Dimitrov, Z. P. (2015). Improving of the Microbiological and Proteolytic profile of Kashkaval Cheese by Modification in heat Treatments of cow's Milk and Cheddared Curd. Journal of Microbiology, Biotechnology and Food Sciences, 4(6), 546-549. https://doi.org/10.15414/jmbfs.2015.4.6.546-549

Grandison, A. (1986). Causes of variation in milk composition and their effects on coagulation and cheese making. Dairy Industries International, 51(3), 21-24.

Haenlein, G. F. W. (1993). Producing quality goat milk. International Journal Animal Science, 8, 79-84. 
Jandal, J. M. (1996). Comparative aspects of goat and sheep milk. Small Ruminant Research, 22(2), 177-185. https://doi.org/10.1016/S09214488(96)00880-2

Kasapidou, E., Basdagianni, Z., Papadopoulos, V., Karaiskou, C., Kesidis, A., \& Tsiotsias, A. (2021). Effects of Intensive and Semi-Intensive Production on Sheep Milk Chemical Composition, Physicochemical Characteristics, Fatty Acid Profile, and Nutritional Indices. Animals, 11(9), 2578. https://doi.org/10.3390/ani11092578

Milewski, S., Ząbek, K., Antoszkiewicz, Z., Tański, Z., \& Sobczak, A. (2018). Impact of production season on the chemical composition and health properties of goat milk and rennet cheese. Journal of Food and Agriculture, 30(2), 107-114. https://doi. org/10.9755/ejfa.2018.v30.i2.1602

Muldasheva, A. Kh., Toxanbayeva, B. O., Ospanov, A. B., \& Zhakupova, G. N. (2019). Study of the composition and properties of sheep milk in Northern Kazakhstan. Eurasian Journal of Biosciences, 13(2), 1997-2000. URL: http://www. ejobios.org/article/study-of-the-compositionand-properties-of-sheep-milk-in-northernkazakhstan-7364 (дата обращения: 07.04.2021)

Myrkalykov, B., Tulekbaeva, A., Shingisov, A., Ospanov, A., \& Simov, Zh. (2016). The Development of Organization Standarts on Sheep Milk. Bulletin of the National Academy of Sciences of the Republic of Kazakhstan, 6, 17-25.

Ospanov, A., Toxanbayeva, B. (2020). Switching to sheep's milk industry: Problems and prospective. Eurasian Journal of Biosciences, 14(1), 1263-1271. URL: http://www.ejobios.org/article/switchingto - sheeps-milk-industry-problems-andprospective-7625 (дата обращения: 07.04.2021)
Ospanov, A., Zhakupova, G., \& Toxanbayeva, B. (2018). Solving the Problem of Serum Utilization in Kazakhstan. International Journal of Engineering \& Technology, 7(3.19), 200-205. https://doi. org/10.14419/ijet.v7i3.19.17337

Pandya, A. J., \& Ghodke, K. M. (2007). Goat and sheep milk products other than cheeses and yoghurt. Small Ruminant Research, 68(1-2), 193-206. https:// doi.org/10.1016/j.smallrumres.2006.09.007

Park, Y. W. (2007). Rheological characteristics of goat and sheep milk. Small Ruminant Research, 68(1-2), 73-87. https://doi.org/10.1016/j.smallrumres.2006.09.015

Park, Y. W., Juárez, M., Ramos, M., Haenlein, G. F. W. (2007). Physico-chemical characteristics of goat and sheep milk. Small Ruminant Research, 68(1-2) 88-113. https://doi.org/10.1016/j.smallrumres.2006.09.013

Saini, A. L., \& Gill, R. S. (1991). Goat milk: An attractive alternate. Indian Dairyman, 42, 562-564.

Sajko-Matutinović, L., Pavić, V, Mioč, B., Antunac, N., Prpić, Z., Matutinović, S., \& Vrdoljak, J. (2012). Sezonske promjene nekih fizikalno-kemijskih odlika mlijeka ovaca dalmatinske pramenke. Journal Mljekarstvo, 62(2), 136-142. URL: https:/hrcak.srce. $\mathrm{hr} / 83363$ (дата обращения: 07.04.2021)

Tamime, A. Y., Wszolek, M., Božanić, R., \& Ozer, B. (2011). Popular ovine and caprine fermented milks. Small Ruminant Research, 101(1-3), 2-16. https:// doi.org/10.1016/j.smallrumres.2011.09.021

Walstra, P, Geurts, T. J., Noomen, A., Jellema, A., \& van Boekel, M. A. J. S. (1999). Dairy Technology: Principles of milk properties and processes. New York: Marcel Dekker.

Zeman, F. J., \& Ney, D. (1982). Clinical nutrition and dietetics. (3rd ed.). Lexington, Massachusetts: Callamore Press. 


\title{
The Research \\ of the Physical-Chemical Composition and Technological Properties of Sheep and Goat Milk During the Summer Lactation Period
}

\author{
Assan B. Ospanov \\ Kazakh Scientific Research Institute of Processing and Food Industry LLP \\ 238 “G” Gagarin Ave., Almaty, 050060, Republic of Kazakhstan \\ E-mail:a.ospanov@rpf.kz
}

Botagoz O. Kulzhanova

Kazakh Scientific Research Institute of Processing and Food Industry LLP 238 “G” Gagarin Ave., Almaty, 050060, Republic of Kazakhstan

E-mail: botagoz-89@mail.ru

Elena M. Shchetinina

Moscow State University of Food Production 11 Volokolamsk Highway, Moscow, 125080, Russian Federation

E-mail: schetinina2014@bk.ru

Shukhrat M. Velyamov

Kazakh Scientific Research Institute of Processing and Food Industry LLP 238 "G" Gagarin Ave., Almaty, 050060, Republic of Kazakhstan

E-mail:sh.velyamov@rpf.kz

Raushan K. Makeeva

Kazakh Scientific Research Institute of Processing and Food Industry LLP 238 "G" Gagarin Ave., Almaty, 050060, Republic of Kazakhstan

E-mail:r.makeyeva@rpf.kz

Maya D. Bektursunova

Kazakh Scientific Research Institute of Processing and Food Industry LLP 238 “G” Gagarin Ave., Almaty, 050060, Republic of Kazakhstan

E-mail:m.bektursunova@rpf.kz

\begin{abstract}
The article presents the results of the research of the physical-chemical composition and technological properties of sheep and goat milk during the summer lactation period (from June to August 2021) on 4 breeds of sheep (Kazakh fine-fleeced, South Kazakh merino, Yedilbay and Ile De Franz) and 4 breeds of goats (Zaanen, Nubian, Alpine and Boer) from various regions of Kazakhstan. Due to the fact that the quantity and quality of milk largely depend on the feed and, accordingly, the season of the year, changes in the fat and protein content were studied. The difference in the protein content in the summer period does not exceed from 0.1 to $0.5 \%$, the high fat content was noted in August (5.4\% for sheep and 3.6\% for goats), and the lowest in July (4.9\% for sheep and 3.2 \% for goats)/ This is due to climatic conditions, in July there is hot weather and animals drink more water and experience the stresses of weather anomalies, and in summer the basis of the ration is pasture herbage, animals consume green fodder containing a lot of moisture. In August, the values of the indicators increase, since many forage crops are maturing by this time and the nutritional value increases accordingly.
\end{abstract}

Keywords: milk, sheep's milk, goat's milk, summer lactation period 


\section{References}

Chetinina, E. M., Gavrilova N. B., Shernopolzki N. L. \& Solovieva N. I. (2021). Innovasionnay technologia polutverdoga syra iz koziego moloka dla spesializirovannogo pitania. [Storage and processing of farm products], 1, pp. 93-104.

Myrkalykov, B. S., Ospanov, A. B., Simov, Zh. I., \& Shingisov, A. U. (2016). Razrabotka potrebitel'skikh kriteriev dlya otsenki kachestva markirovki ovech'ego moloko i produktov ego pererabotki [Development of consumer criteria for assessing the quality of labeling of sheep milk and products of its processing]. Issledovaniya, rezul'taty [Research, results], 4, 120-131.

Ospanov, A. B., Alimardanova, M. K., \& Toksanbaeva, B. O. (2017). Potentsial molochnoi otrasli Kazakhstana [Dairy industry potential in Kazakhstan]. In Tekhnika i tekhnologiya pishchevykh proizvodstv: Materialy XI mezhdunarodnoi nauchno-tekhnicheskoi konferentsii [Technique and technology of food production: Proceedings of the XI international scientific and technical conference] (pp. 13-15). Mogilev: Mogilevskii gosudarstvennyi universitet prodovol'stviya.

Ospanov, A. B., Alimardanova, M. K., \& Toksanbaeva, B. O. (2018). Sostav ovech'ego i koz'ego moloka v Kazakhstane [The composition of sheep and goat milk in Kazakhstan]. In Tekhnika i tekhnologiya pishchevykh proizvodstv: Materialy XII mezhdunarodnoi nauchno-tekhnicheskoi konferentsii [Technique and technology of food production: Proceedings of the XII international scientific and technical conference] (vol. 1, pp. 373-374). Mogilev: Mogilevskii gosudarstvennyi universitet prodovol'stviya.

Shchetinina, E. M., Gavrilova, N. B., Chernopol'skaya, N. L. \& Solov'eva, N. I. (2021). Innovatsionnaya tekhnologiya polutverdogo syra iz koz'ego moloka dlya spetsializirovannogo pitaniya [Innovative technology of semi-hard cheese made from goat's milk for specialized nutrition]. Khranenie i pererabotka sel'khozsyr'ya [Storage and Processing of Farm Products], 1, 93-104. https://doi. org/10.36107/spfp.2021.193

Babayan, V. K. (1981). Medium chain length fatty acid esters and their medical and nutritional application. Journal of the American Oil Chemists Society, 59, 49-51. https://doi.org/10.1007/BF02666072

Claeys, W. L., Verraes, C., Cardoen, S., De Block, J., Huyghebaert, A., Raes, K., Dewettinck, L., \& Herman, L. (2014). Consumption of raw or heated milk from different species: An evaluation of the nutritional and potential health benefits. Food Control, 42, 188-201. https://doi.org/10.1016/j. foodcont.2014.01.045
Dimitrov, D., Simov, Zh., Ospanov, A., \& Dimitrov, Z. P. (2015). Improving of the Microbiological and Proteolytic profile of Kashkaval Cheese by Modification in heat Treatments of cow's Milk and Cheddared Curd. Journal of Microbiology, Biotechnology and Food Sciences, 4(6), 546-549. https://doi.org/10.15414/jmbfs.2015.4.6.546-549

Grandison, A. (1986). Causes of variation in milk composition and their effects on coagulation and cheese making. Dairy Industries International, 51(3), 21-24.

Haenlein, G. F. W. (1993). Producing quality goat milk. International Journal Animal Science, 8, 79-84.

Jandal, J. M. (1996). Comparative aspects of goat and sheep milk. Small Ruminant Research, 22(2), 177-185. https://doi.org/10.1016/S09214488(96)00880-2

Kasapidou, E., Basdagianni, Z., Papadopoulos, V., Karaiskou, C., Kesidis, A., \& Tsiotsias, A. (2021). Effects of Intensive and Semi-Intensive Production on Sheep Milk Chemical Composition, Physicochemical Characteristics, Fatty Acid Profile, and Nutritional Indices. Animals, 11(9), 2578. https://doi.org/10.3390/ani11092578

Milewski, S., Ząbek, K., Antoszkiewicz, Z., Tański, Z., \& Sobczak, A. (2018). Impact of production season on the chemical composition and health properties of goat milk and rennet cheese. Journal of Food and Agriculture, 30(2), 107-114. https://doi. org/10.9755/ejfa.2018.v30.i2.1602

Muldasheva, A. Kh., Toxanbayeva, B. O., Ospanov, A. B., \& Zhakupova, G. N. (2019). Study of the composition and properties of sheep milk in Northern Kazakhstan. Eurasian Journal of Biosciences, 13, 1997-2000. URL: http://www.ejobios.org/article/study-of-the-composition-andproperties-of-sheep-milk-in-northern-kazakhstan-7364 (accessed: 07.04.2021)

Myrkalykov, B., Tulekbaeva, A., Shingisov, A., Ospanov, A., \& Simov, Zh. (2016). The Development of Organization Standarts on Sheep Milk. Bulletin of the National Academy of Sciences of the Republic of Kazakhstan, 6, 17-25.

Ospanov, A., Toxanbayeva, B. (2020). Switching to sheep's milk industry: Problems and prospective. Eurasian Journal of Biosciences, 14(1), 1263-1271. URL: http://www.ejobios.org/article/switchingto-sheeps-milk-industry-problems-and-prospective-7625 (accessed: 07.04.2021)

Ospanov, A., Zhakupova, G., \& Toxanbayeva, B. (2018). Solving the Problem of Serum Utilization in Kazakhstan. International Journal of Engineering \& Technology, 7(3.19), 200-205. https://doi. org/10.14419/ijet.v7i3.19.17337

Pandya, A. J., \& Ghodke, K. M. (2007). Goat and sheep milk products other than cheeses and yoghurt. 
Small Ruminant Research, 68(1-2), 193-206. https:// doi.org/10.1016/j.smallrumres.2006.09.007

Park, Y. W. (2007). Rheological characteristics of goat and sheep milk. Small Ruminant Research, 68(1 2), 73-87. https://doi.org/10.1016/j.smallrumres.2006.09.015

Park, Y. W., Juárez, M., Ramos, M., Haenlein, G. F. W. (2007). Physico-chemical characteristics of goat and sheep milk. Small Ruminant Research, 68(1 2) 88-113. https://doi.org/10.1016/j.smallrumres.2006.09.013

Saini, A. L., \& Gill, R. S. (1991). Goat milk: An attractive alternate. Indian Dairyman, 42, 562-564.

Sajko-Matutinović, L., Pavić, V, Mioč, B., Antunac, N., Prpić, Z., Matutinović, S., \& Vrdoljak, J. (2012). Sezonske promjene nekih fizikalno-kemijskih odlika mlijeka ovaca dalmatinske pramenke
[Seasonal changes in some physical and chemical qualities of the milk of Dalmatian sheep strands]. Journal Mljekarstvo [Journal of Dairy Farming], 62(2), 136-142. URL: https://hrcak.srce.hr/83363 (accessed: 07.04.2021)

Tamime, A. Y., Wszolek, M., Božanić, R., \& Ozer, B. (2011). Popular ovine and caprine fermented milks. Small Ruminant Research, 101(1-3), 2-16. https:// doi.org/10.1016/j.smallrumres.2011.09.021

Walstra, P, Geurts, T. J., Noomen, A., Jellema, A., \& van Boekel, M. A. J. S. (1999). Dairy Technology: Principles of milk properties and processes. New York: Marcel Dekker.

Zeman, F. J., \& Ney, D. (1982). Clinical nutrition and dietetics. (3rd ed.). Lexington, Massachusetts: Callamore Press. 